\title{
Experiences from Implementation of Lean Production: Standardization versus Self-management: A Swedish Case Study
}

\section{Margareta Oudhuis'}

Ass. Professor, School of Education and Behavioural Sciences, University of Borås, Sweden

\section{Stefan Tengblad}

Professor, School of Economics and Social Science, University of Skövde, Sweden

\begin{abstract}
In this article, we discuss important aspects of the perceived problematic relationship between self-management and standardization. The article presents data from three case studies conducted within manufacturing companies in Sweden, where the popularity of lean production has led to a renaissance for short-cycle and standardized assembly work in settings that traditionally have made use of sociotechnical production design. The data suggest that the implementation has not contributed to an increased commitment, smooth operations, and capacity for change and innovation. Despite these not so positive results, it is argued that it is possible to combine self-management principles with lean production and standardization if I) the implementation of lean is done with a contextual sensitivity, 2) a balance is reached between the use of standards on the one hand and work enrichment on the other, and 3) a feeling of ownership as regards both implementation and production process is upheld among the production personnel.
\end{abstract}

\section{KEY WORDS}

Heijunka / kaizen / lean production / sociotechnique / standardization / Sweden

\section{Introduction}

ean production is one of the most influential management and organizational trends globally in the last decade. Even though it is a concept not possible to define exactly (Seppälä and Klemola, 2004), lean production can be perceived as a way of thinking toward which organizations strive through acquiring certain principles and by implementing various tools and technologies (Womack et al., 1990). These tools and technologies are commonly seen as originating from a Japanese production context and were popularized throughout the world from the 1990s. One important and necessary constituent of the lean concept is the use of standards, which is of particular interest in this article, dealing with the relationship between standardization and self-management in a Swedish context. Being part of a globalized world, the Swedish working life is heavily affected by these lean models. The more popular they have become, the more obvious is the problematic relationship between self-management and standardization, based on

\footnotetext{
${ }^{1}$ E-mail: Margareta.Oudhuis@hb.se
} 
our definition of self-management as autonomy at work and self-regulation (Niepce and Molleman, 1998; see further below) and standardization as narrow short-cycle work, a common lean trait in the manufacturing industry. The reason why this problem is more accentuated in the Scandinavian countries in general and in Sweden in particular is the impact sociotechnical production models have had since the end of the 1970s.

Research shows that even though there has been a general development toward a higher degree of self-management in many European countries (Totterdill et al., 2002), it has not been followed by a significant higher degree of influence at work (European Foundation, 2007). Two possible explanations are given, one of them pointing to the fact that autonomy linked to self-management is counteracted by an increase in standardization (Thompson, 2003), leading to psychosocial strain at work (Docherty et al., 2002). Secondly, that organizations characterized by self-management often lack routines and standards which in turn could lead to a boundless work situation with different kinds of negative work environment consequences (Allvin et al., 2006; Visholm, 2005).

In the article, we argue that it is not inevitable that implementation of lean processes will have detrimental effects on work satisfaction and other values associated with sociotechnical production models. Studies have shown that the implementation of lean can be performed quite differently with very different outcomes. It might be the case that lean production is implemented with a contextual sensitivity, that is, with the ability to consider the context in which the lean model will be set up, and do it in ways that will prove effective in that specific context (Börnfelt, 2006; Hailey and Balogun, 2002; Hasle et al., 2012; Pettigrew and Whipp, 1991). Successful change, in the Swedish case, thus would require a context-sensitive approach in which lean practices are combined with established models for job enrichment, involvement, and delegated responsibilities.

By focusing on the implementation of lean, the aim of the study is to explore if lean and self-management principles can be combined or if the differences between the principles are too wide. We will address this overall research aim with the help of the following research questions:

- What are the experiences in three different manufacturing units, where there has been a tradition of sociotechnical work design, when implementing and practicing lean?

- To what extent is lean implementation (with standardization as a strong characteristic) affecting the possibility of practicing self-management and upholding work richness and other sociotechnical aspects?

The empirical material consists of three Swedish case studies from companies in the mechanical engineering industry, all of them with a tradition of sociotechnical practices. In recent years, however, the companies have launched substantial efforts for implementing lean practices. In particular, we will focus on the consequences for production personnel.

The structure of the article is as follows: In the next section, the theoretical principle focusing on a description of sociotechnical versus lean designs is presented. Thereafter, the methodological issues are discussed and the case study settings presented. The result section then revolves around the experiences of the implementation of lean in each of the three cases. Finally, the analysis consists of the interpretation of the results in relation to the research aim and questions followed by a discussion about research implications and contribution. 


\section{Research overview}

As indicated in the introduction, the Swedish working life has been influenced by a sociotechnical movement involving union and employer representatives, researchers, consultants, shop floor managers, and production engineers (Hofstede, 1991; Jönsson, 1995; Tengblad, 2003). This movement was extraordinarily influential in the first half of the 1990s when The Swedish Working Life Fund distributed 10 billion Swedish crowns to 25.000 work development projects that were put in action in almost all sectors of the Swedish work life (Gustavsen, 1996). The sociotechnical way of organizing emanates from work life experiments in Britain, Norway, and Sweden from the early 1960s. Volvo's factories in Kalmar and Uddevalla are two examples that have received large national and international attention. Nevertheless, sociotechnical work design has not been as common outside the Scandinavian countries and is indeed a unique feature of this region regarding work organization.

Sociotechnical work design is aiming at full work content for operators including delegated white collar tasks, team work with a minimum of specifications, self-regulation, and a high degree of influence and participation as some of its corner stones (Niepce and Molleman, 1998; Thorsrud and Emery, 1969; Susman, 1976). To be noted is that minimal specifications, accordingly the contrary to standards, are seen as a means for operators to develop better and better ways of performing work through experimentation and learning. The associated leadership style emphasizes the importance of delegating responsibilities and authorities giving opportunities for autonomy and development at work. In that way, the argument goes, the company and organization will benefit from operators' creativity and innovative capabilities, contributing to an increase in productivity, quality, and efficiency. Thus, one important aspect of sociotechnical work design is self-management, i.e., that groups of operators are able to perform activities commonly associated with decision-making powers and supervisory work such as work scheduling, coordination, having contacts with suppliers and customers, and to be involved in quality control and maintenance work.

However, as pointed out above, during the last decade, Sweden has been heavily influenced by the lean movement spreading across the world. Lean is not only a way of organizing, but embraces a new production philosophy with its origin in Japanese culture. The American influence in spreading the lean concept is, however, not less strong, for instance, with the books The machine that changed the world (Womack et al., 1990) and The Toyota Way (Liker, 2004), two of the most prominent examples. Leaning on these books, lean has not only been strongly promoted by consultants but also at universities, to the disadvantage of sociotechnical design.

As regards lean, some of its most distinctive characteristics have to do with reducing waste, customer order management, minimizing buffers, kaizen activities, a high degree of standardization, and measurability (Hampson, 1999). Team organization is another prominent aspect, but also the use of experts, usually limiting operators' participation in decision making (Niepce and Molleman, 1998). Since cycle times are short, not seldom only 1 minute long, operators often find themselves in a stressful and less satisfying work situation with a narrow work content, a considerably lower degree of self-development, and capacity for innovative performance (Börnfelt, 2006; Hasle et al., 2012; Landsbergis et al., 1999; Oudhuis and Olsson, 2011). Still, operators' innovative and creative capacities are needed and of great importance in order to ensure the impact of continuous improvements. 
Besides, the prevailing global management trends from the United States advocating a strongly authoritarian leadership fit the lean concept quite well with its need for a more centralized leadership with a high degree of direct and indirect control using standards and detailed specifications as disciplinary techniques (Björkman, 2002; Hampson, 1999; Røvik, 2000).

Nevertheless, standardization in relation to worker autonomy is looked upon very differently. On the one hand, standardized processes are perceived as reducing worker autonomy almost completely as pointed to above (see also Hackman and Oldham, 1975, 1976, 1980), while de Treville and Antonakis (2006) argue that workers who experience reduced levels of autonomy can still be motivated if other job-design factors make up for it. Besides, autonomy does not have to be interpreted as freedom concerning procedures and timing as is the case in sociotechnical practices, but can also be interpreted as responsible autonomy, i.e., the degree to which workers are actively setting rules, such as standard procedures, by which they are limited, if these limitations are in accordance with expected performance improvements and work-related needs (de Treville et al., 2005).

Furthermore, standard operation procedures (SOPs) can be perceived as leading to work facilitation. Imai (1986:xxiv) defines SOPs as "a set of policies, rules, directives, and procedures for all major operations, which serve as guidelines, thereby enabling employees to perform their jobs successfully." Lean proponents also insist that the use of standards is the tool behind workers taking on true responsibility (de Treville and Antonakis, 2006) and that access to accurate SOPs increases worker confidence (Adler, 1993). SOPs are also claimed to be the mechanism by which employee ideas are transformed into business practice, increasing workers' perceptions of participation (de Treville et al., 2005; Edelson and Bennett, 1998). Participation in lean practices thus equals the development of standard operating procedures (de Treville and Antonakis, 2006). Moreover, limited resources provide challenging goals and thereby increase motivation. According to de Treville and Antonakis (2006:119), lean therefore can be motivating for workers through the use of responsible autonomy, work facilitation, and self-efficacy. However, to argue that participation (and autonomy) could be equated with taking part in standardization work is by far too narrow a definition of participation according to lean opponents. Many more elements need to be included for participation to exist. Besides, scarcity of resources rather implies that workers have neither the time nor the energy to put into creative problem solving. Excessive leanness is instead liable to result in complete worker alienation (Kamata, 1982). Also, proponents agree that excessive leanness is an abomination leading away from all positive elements in lean.

According to Hasle et al. (2012) who examine 38 studies (31 from the United States and Canada, 6 from the United Kingdom and 1 from Finland, of which 13 covered the auto industries, 11 the health sector, and 1 telecommunications), the lean concept is implemented in a variety of ways, and thus the specific lean design can take many different forms. However, Hasle et al. propose a strong focus on the human side, arguing that lean must be regarded not only as tools but as an integrated part of a broader sociotechnical system. This is an argument we agree upon. In one of the reviewed studies, Landsbergis et al. (1999) draw a clear and negative picture as regards the auto industry with intensified work pace and increased demands, while job control remained low. One exception was a British company using employee participation. Conti et al. (2006) in turn had surveyed 21 sites with 1391 employees who were engaged in assembly work in 
the manufacturing industry in the UK. They found that whether lean is mean depends on the design and operation of the lean system. Although the negative effects dominated, employee involvement in the implementation had a positive effect.

In general, the various studies in Hasle et al. (2012) show that lean can result in lower job autonomy, especially as regards timing and method control. Furthermore, higher demands, work pace, workload, and work intensity are common outcomes leading to feelings of tension, exhaustion, job-related depression symptoms, lower self-efficacy, stress, and anxiety. The studies published from 1999 onward therefore confirm the findings of Landsbergis et al.'s (1999) review, indicating that lean has a negative impact not only on employees in the auto industry but also on manual work with low complexity more generally. But there are also examples of positive outcomes. Several studies indicate that the outcome depends on the implementation (how lean is introduced, top-down or bottom-up) as well as the context (such as a harsh environment with many conflicts or a context with high levels of trust).

Positive effects of lean were for example found in a study by Seppälä and Klemola (2004), indicating that the extent of employee involvement in the implementation process is especially important for employee behavior. Their results indicate that integrating lean in a larger change program, based on the Scandinavian tradition for sociotechnique and employee involvement, could be the decisive factor, a finding underlined by Börnfelt (2006). Hasle et al. (2012) thus conclude that the outcome of lean implementation has to do not only with how lean elements are applied but also on the implementation process and the context. To prevent negative effects on the working environment and employee health and well-being, the involvement of employees, both in lean implementation and in lean practices, seems to be the most important means. Lean, therefore, has to be examined as a sociotechnical system, not as a set of tools.

With Hampson (1999), we would also like to point to lean as a Japanese production philosophy that contains different ways or possibilities to organize production, which includes aspects that compete with one another. Lean can on the one hand be committed to leanness through understaffing, i.e., be used and implemented as a speed-up technique. This is achieved through making production more vulnerable by removing buffers and slack, by stressing the system to the verge of breaking down, thereby identifying sites where the production process needs to be redesigned and improvements to be won. Standards and kaizen work, in turn, cause pressure since such improvements, contributed to by operators, are manifested on standard work sheets, which in turn provide the base for further improvements. The problem with this kind of organizational learning, i.e., appropriating innovations that become standard practice, is that operators hereby in fact often end up contributing to an increase of their own workload, since the system appropriates that knowledge instead of operators being able to use their knowledge of the production process to protect themselves against pacing (Dohse et al., 1985 in Hampson, 1999).

However, in Japan, there are also examples of plants partly moving away from such adaptations of leanness, comprising the end of practicing short-notice overtime and time buffer at the end of the day. These examples include a limited use of Just-In-Time, while allowing a greater emphasis on internal buffers (Hampson, 1999:383) and other more humanized ways of producing, building on a concept called heijunka. Heijunka was introduced in order to counter different kinds of imbalances in the Toyota Production System but also as a strategy to meet market demands and fluctuations, while still carrying 
as little work in progress stock as possible. Heijunka means a "balanced," "smoothed," or "leveled" production. It is about achieving a more even production process by avoiding situations where one part of the process is working at a low capacity level, while another is overworked. Put it differently, production management has to balance losses from standstills against losses from carrying inventory where multiple products are produced on the same line. In order to produce complex products, one has to be able to adjust to changes in demand or variations of different models.

This in turn requires production to be planned in advance in very refined ways, to find different ways of "leveling" production over time. Furthermore, heijunka also aims at "balancing" the workload between workers as well as the capacity of machines and operators to finalize the job (Shingo, 1989; cited in Coleman and Vaghefi, 1994:31 in Hampson, 1999). Since imbalanced production procedures promote waste, there is a strong tension between kaizen and heijunka, which is emphasized when reducing buffers and work in progress inventory. Pushing kaizen is therefore the opposite of heijunka, since heijunka presupposes a balanced workload in line with the capacity of operators and machines. Moreover, since kaizen activities often are caused by waste from unscheduled fluctuations in everyday work volume, there is according to Hampson (1999) a give-and-take between what is achieved through leveled production and what is gained by removing buffers to push kaizen.

A crucial point is therefore to reach a balance between kaizen activities and heijunka. The balancing outcome depends on who is to bear the costs and benefits, in turn depending on involved parties' relative power resources. Some industrial relations systems, such as union power, reject extremes of leanness, and conversely, if union power does not exist, truly lean (and mean) models are enabled. There is thus a choice not only between management strategies that emphasize beijunka and production continuity or leanness and kaizen as Hampson (1999) suggests but also between strict lean practices and modified versions that include sociotechnical and self-management features (cf. Börnfelt, 2006; Seppälä and Klemola, 2004).

In summary, there are many different choices to be made when implementing lean practices and standardization in the Swedish work life, indicating the possibility to take contextual considerations as regards not only the process of change when implementing lean practices but also when choosing lean elements that apart from fitting the actual setting also would provide opportunities for work richness and a sense of self-management.

\section{Methodology and setting}

In this paper, we will use material from three shop floor case studies in different mechanical engineering plants where issues on standardization and self-management have come to the fore in different ways. The companies were all involved in change processes, leaving their sociotechnically inspired practices while introducing lean models. In order to preserve anonymity but still facilitate discernment, the three companies will be called East, West, and North.

Two of the case study companies were taken over by different Japanese worldwide companies, one of them, East, in the beginning of 2000 and the other one, the West plant, a few years later. The third plant is part of a Swedish-owned global corporation. 
Semi-structured interviews of up to or more than 2 hours were conducted in all three plants according to Table 1 and serve as the main unit of analysis in this article. The interviews had the form of long, rather informal talks (Silverman, 2006). Feedback meetings with management and union representatives were also part of the setup in all three studies. Two of them, West and North, were conducted at the same time and also included surveys covering all employees at the two companies. In this article, however, we mainly concentrate on the interviews in order to get a more comparable picture between the three plants, taking into regard the fact that the East case includes a rather great number of interviews with operators (which is not the case in West and North).

Table I Number of employees and interviews and positions at the three plants.

\begin{tabular}{lccl}
\hline Plant & $\begin{array}{c}\text { Number of } \\
\text { employees }\end{array}$ & $\begin{array}{c}\text { Number of } \\
\text { interviews }\end{array}$ & Positions \\
\hline East = Japanese owner & 1700 & 28 & $\begin{array}{l}\text { Management on different levels, } \\
\text { operators, union representatives }\end{array}$ \\
\hline West = Japanese owner & 300 & 6 & $\begin{array}{l}\text { Management on different levels, } \\
\text { union representatives }\end{array}$ \\
\hline North = Swedish owner & 300 & 6 & $\begin{array}{l}\text { Management on different levels, } \\
\text { union representatives }\end{array}$ \\
\hline
\end{tabular}

In the East case, the research focuses on the impact of cultural and value aspects when implementing lean production, and the rather severe conflicts and dilemmas that arose. The selection of interviewees was done in order to get hold of key people including a representative for the Japanese owner and also persons with known positive and negative views on lean production. As regards the West and East cases, the overall aim was to understand the reasons for conducted changeovers from sociotechnical models to lean but also to study the consequences of and reactions to these changes.

\section{Results from the three case studies}

\section{The East plant}

The East plant was overtaken by a Japanese owner in the beginning of 2000, a global corporation well known for its long-term experience and knowledge of lean production. The Swedish subsidiary is one of the leading players within its branch and together with the Japanese owner they are the market leader in the world. Since it was the first already existing company that was acquired by the Japanese combine, the plant had a rather high degree of autonomy during the first years. The owner took its time to learn about the plant, noticing the small number of white collar staff compared with the Japanese head plant. Still, in connection with the takeover, the Swedish management decided to start implementing a locally adapted lean production model, a model that included clear sociotechnical aspects. Even so, the switch meant they were leaving their former station assembly model with operator work content of up to a week building a com- 
plete product. Moreover, the sociotechnical model included partly self-directed teams of 8-15 members having a great deal of decision-making power. The groups were responsible for solving absence and leaves, for introducing newcomers, and have a say as regards overtime. Their responsibilities also covered inventory, material handling, and achieving weekly goals and so forth.

Successively however, the grip from the owner was strengthened, implying a switch to a Japanese/TPS-oriented model (Toyota Production System) along line assembly. Work content has thereby been heavily reduced with cycle times of between 6 and 25 minutes, an increase of standardization has been at hand, buffers are set to a minimum, and weekly goals are replaced by daily goals leading to a more stressful work situation for the operators. Besides, a new profession was brought in consisting of those in charge of the sequence order, another lean characteristic.

The wish for operator autonomy in relation to standards clearly came to the fore. According to the production manager, Swedish operators are "more of artists" wanting to do things "their own way," which makes it difficult to bring in detailed standards. One operator in turn put it this way: "If I know I am right I do it my own way." Another one stated that:

We do what we are asked to do, though we might not do it the way they want us to, but in our own way. And sometimes we do it exactly as we are asked to, if that happens to be the best way.

Moreover, many operators found it difficult to understand why one should not build a buffer (at least a small one) or why what is effective from an individual point of view can cause problems for the production as a whole. Why should one follow the sequence order as a welder when it would be so much more effective to keep producing similar articles without having to reset the machine so many times? The feeling of not being listened to in combination with a lack of understanding the lean concept is underlined by another operator referring to his wishes to uphold a buffer:

If I am supposed to do eight pieces, then eight pieces come (to me) and not a single more.

The fact that I would like to get ten doesn't matter.

The breakdown of communicating the benefits of this kind of principles obviously created a feeling of being overrun. Besides, people are used as the elastic band and the idea is to send people home when production is running low instead of using available time for competence development. Even if rotation is strived for, only every seventh operator gets the chance to actually take part in rotation. The rest is to be governed and more or less expected to stand put. While many of the older operators are very negative toward the development, others are more resigned. Leadership has become more authoritarian and operators' decision-making powers have been heavily reduced. "One is put under the axe" as one of the interviewees put it.

On the positive side, many of the operators still feel quite proud working for their world-known Japanese owner. The changes have also led to a much better order at the workplace and to a successful handling of waste reduction. Moreover, focusing on production and production issues from all concerned parties makes sure imperfections are dealt with much more rapidly, supporting an increase of profitability and productivity. 
At the same time, the number of white collar staff has increased, making sure the demands connected to the implementation of lean will be fulfilled (Oudhuis and Olsson, 2011).

As regards professional pride, the switch to lean has brought about a less strong pride of craftsmanship among operators due to a loss of skills and withdrawn team responsibilities. As one of them put it:

Today I am just a brick in the game.

He has to accept it, "but it means one doesn't care as much as before, one does what one is supposed to do, but not much more." The bottom-line seems to be the loss of influence and self-determination, of having lost that special feeling of ownership over production, but also of understanding the production process as a whole. On the other hand, operators have more information about their own performance in relation to the production goals, quality issues, and so forth of their own line. But only to their own production line.

\section{The North plant}

The North case covers a production plant within a Swedish global corporation with around 300 employees, not counting temporary staff employed by a personnel agency. By the time of the study, an edict from the head office was issued stating that all plants, regardless of product type and production design, had to implement the same Japaneseoriented lean model. Earlier, different production models were in use, but today only lean is allowed, whether the lean concept is in harmony with the actual production or not. Instead, management at the head office has an almost blind belief in lean, "it is unobjectionable, what could be wrong with lean?" as the head of plant described their view, even if the prerequisites are not there.

For the plant in question, it meant leaving their own locally adapted line assembly model along sociotechnical lines, which at the time was in a remodeling phase due to some inherent problems. In the previous model, all operators had possibilities to rotate between different stations (including preparatory stations) but also to take on and rotate between different roles, such as team leader, technical support, support for economy and for personnel, and so forth. Also, improvement groups had been introduced combined with a coaching leadership style. The remodeling lean-inspired model included a centralization of the preparatory stations and a withdrawal of support roles with a reduction of work richness as a result. Still, cycle times are relatively long, between 41 and 82 minutes. After the edict, a more strict Japanese lean implementation process was set in motion, which included lean tools such as daily goals (instead of weekly), a takt system, standardized work sheets, daily meetings, order and neatness, visualization boards, reduction of waste, and so forth.

However, even though some lean tools have been implemented more successfully, the implementation process immediately ran into major problems. Kaizen groups were abandoned for a relatively long period of time, introduction of standardized work sheets failed almost at once, as was the case with firm takt times. Some of the tools have contributed to reduced skills, increased stress and negative attitudes, and incomprehension 
of the rationality of lean. One such issue has to do with handling deviations; today operators are supposed to hold up a hand when something is not working and keep continuing with the assemble work instead of handling occurring problems by themselves. As one of the interviewees put it:

You don't take part in deviations today as was the case when we had docks. Then we handled the deviations ourselves. Today you simply hold up your hand "this is not working" and another guy takes care of the problem. And the operator continues with what he has to do. In the docks I fixed it myself. Even if I got help, I was responsible for fixing the deviation myself in a completely different way.

The above reflection thus makes evident that a strong feeling of ownership and responsibility for production has been replaced by an insight of being there just to assemble and nothing else. Besides, skilled operators who were able to assemble a whole vehicle are not getting the same possibilities to use their skills today. Trying to argue for a different practice was, however, according to the head of plant, unthinkable:

It would be to swear in church. Lean must be!

As regards firm takt times, lean as a strong context-dependent production model clearly came to the fore at this plant with its cycle times of 41-82 minutes depending on the model. When bringing in firm takt times, every station was supposed to move in accordance with the time table with exact moving times. Problems, however, occurred more or less directly, since every now and then one or another station was 5 or 10 minutes behind schedule. That meant a standstill for the whole line waiting for the next move, sometimes up to 1 hour. According to one of the line leaders, heavy discussions followed. Keeping the brought in takt was considered such a waste that a decision was made to ignore the takt and take the delay: "If we ever change takt, it is the first takt in the morning." In this way, the delay is usually taken care of during the day keeping the scheduled number of products. At times, operators also assemble pieces of material at the next station just to keep up the pace or leave the product and complement it afterward. One reason for the failure has to do with the unwillingness to invest in technical equipment such as takt clocks making it possible to adjust the tact. Instead, a system not supported by technology was brought in creating static timetables and thereby lost production time.

The experience of failure when using standardized work sheets was mainly due to the amount of variants, ten models and 18 variants. On top of that, $50 \%$ of the vehicles were customized. One of the production line leaders complained:

We have not succeeded... It is one thing to use lean in a Toyota plant with its hundreds of thousands of cars... but here, with our 3000 units [per year], looking completely different all of them, then you have to open your eyes and see that... here we cannot use all of it. It simply doesn't work...

This means that even though work sheets are still hanging out there, the line leader is "prepared to pull them down, since nobody is using them anyway." Even though he, as a former production engineer, likes the lean concept, the philosophy, he feels that one has to think twice about what is applicable and what is not. 
Other problems with standardized work sheets have to do with the fact that they are based on filming one particular operator finishing a balance on one particular variant of one specific model. That piece of film measuring the time it took for the operator to build but one balance was then used for balancing the whole line, demanding a lot of adjustments in order to get an even balancing throughout the line. But with more than 250 different variants, this is a big problem. Another most vital issue has to do with updating the work sheets with all the small changes that are made in any or all the different work operations. This has proven far too costly, i.e., it costs much more than it tastes. And even when attempts were made to update work sheets, delays were frequent, leading to situations where operators without basic professional skills and knowledge had to follow not updated work sheet instructions in detail, ending up assembling the products in the wrong way.

The above-mentioned difficulties are only some of the problematic features plant managers and operators have faced when trying to bring in firm takt times and standardized work sheets without contextual considerations. To be noted, however, is that the use of standardized work sheets in itself has nothing to do with switching over to a line or with dividing assembly work into short work cycles. Even though these features often accompany each other, there is no necessary connection.

As regards successfully implemented tools or improvements in relation to the changeover to lean, daily meetings with representatives from different departments have been introduced, a stronger focus on quality has had positive effects, and temporary problem-solving groups have been set up and are working fine. Besides, the internal logistics has improved after introducing a two-bin system.

\section{The West plant}

The West plant consists of a former family-owned company that was overtaken by a Japanese company group some years ago. The number of employees is around 300 . The company has undergone some rather extensive changes during the last years in connection with implementing a certain kind of lean model. However, the former station assembly practice for the heaviest products, at times taking days to assemble, still exists and will continue to do so. The switchover to lean thus includes only the smaller products. The lean design is made up of two serial product flows consisting of short assembly lines with integrated preassembly workstations. One of them is constructed in a U-form with an intermediate buffer of three places, while the other one consists of an overhead conveyor, without in-between buffers, forming a closed loop which connects six workstations. Work cycle times are between 30 and 45 minutes, with possibilities to rotate between stations, respectively, to follow the product along the loop.

Apart from practicing a set of commonly known lean tools (much the same as in the above two plants), work organization has been reformed in a number of different ways leading to a less rich work content including strongly reduced authority and autonomy for operators. In the earlier sociotechnical model, a strong sense of self-management had been achieved. Teams of operators were delegated far-reaching responsibilities concerning the daily production including administrative tasks, tasks involving purchasing and calling off material, personnel issues, the need for overtime, and so forth. Besides, 
constructors and operators were working very tightly together with delegated assignments such as customer adjustments. As a result, a feeling of ownership over production was created, resulting in a successive increase of efficiency and profitability as well as of delivery security and quality. Many operators showed great enthusiasm and were highly motivated with a strong feeling of pride. As the production engineer manager declared:

As a result (of the new work organization) there was a tremendous increase of efficiency as well as of delivery security and everything really; including quality. And without changing the way production was carried out, nothing like that, it all had to do with increased motivation.

However, management successively experienced a strong loss of authority, control, and knowledge as regards production and production issues. In turn, operators gradually gained more and more power, creating a strong feeling of ownership over production. Since both operators and management felt they were to be responsible and in charge of setting production goals and so forth, management felt the situation had gone overboard. One way to handle the situation was to bring in lean and thereby regain ownership over production.

According to the head of plant, one main reason for the changeover to lean thus was the arisen power imbalance. Not surprisingly, implementing lean met with great resistance from most operators leading to a long and difficult process, which included operators having to leave the plant but also to a withdrawal of delegated tasks and responsibilities. The end result has been a more peaceful and friendly relationship between management and operators, but at the expense of impoverished work content and a loss of cooperation between construction and production departments. Other consequences, besides a loss of autonomy and of professional pride, are less multifunctional operators. According to the manager for production engineering, the fact that operators are no longer involved in calling off material has also led to efficiency and quality losses in production. However, an overall increase of productivity and quality has been reached and a more orderly and clean shop floor. Also a majority of operators are satisfied with the overall working conditions at the plant. The union vice chairman, on the other hand, proclaims these very same positive results could have been achieved while still holding on to the previous work organization with all its delegated tasks and responsibilities:

...in connection with switching to line work there was all of a sudden a need for more people. We could easily have achieved the same if we had kept our station assembly model, since we now need so many more people.

As regards instruction sheets, there used to be a big difference depending on which department one was working at. Bringing in standardized work sheets has therefore created a considerably less vulnerable production situation. When someone is on sick leave or otherwise absent, there is no problem in keeping production going, there are others who easily fill in, which was not the case before. Besides, all products are ensured to be built in the same way, which again was not always the case before. Transfer of knowledge on how to build a product is also facilitated.

At the same time, a more stressful work situation has been created due to the line assembly, making it difficult for some operators to continue as they grow older. Another 
stressful factor has to do with operators being much more bounded; before leaving a station, a replacer must be called in. Stress also has to do with dependency within teams, since everyone needs to finish his or her work cycle at the same time. If someone is slower than the others, there is a risk for tensions within the teams. Individual operators are even at risk to be unwanted as team members. Operators' loss of self-determination is also pointed to by the plant manager when comparing to how it used to be. "The teams were given a lot of responsibilities and increased work content," whereby they gained a very high degree of autonomy and control over production. As the plant manager put it:

Before operators owned their own time completely.

As shown above, this is not the case anymore. Still, he argues, management has tried to keep operator autonomy to some degree also in the new system. Overall, the result shows that there have been both positive and negative outcomes after the switch to lean practices.

In summary, the above case studies indicate that even contextual adaptions in some forms have been made, thereby keeping a reduced engagement and sense of ownership among operators, but also that it would have been possible and a great advantage if the implementation processes had involved more sociotechnical elements including selfmanagement principles.

\section{Discussion}

Now, what conclusions can be drawn from the three case studies regarding implementing and practicing lean with a contextual sensitivity in relation to standardization and other lean tools on the one hand and self-management and work enrichment on the other?

Overall, it can be concluded that the lack of contextual sensitivity was evident when implementing lean practices in the three case companies, even though contextual considerations partially took place. At the West plant for example, the product context partially was taken into account when accepting that the heaviest products could not be switched from station assembly to line; it would not work. Also at the North plant, some necessary adjustments were introduced when some of the lean tools were obviously not suitable for the product or production context. We would, however, like to argue that one explanation for the more general lack of contextual sensitivity might be the irresistibility of the lean wave in general but also the strong influence lean today has on production engineers. As regards contextual sensitivity, it stands clear that not only is it important to take into account production volumes and the degree of different variants but also the established work organization. Our findings, therefore, indicate that lean production practices are not as generally applicable as its proponents typically claim. The cost of standardizing rather small volumes and customized production can for instance be much higher than the benefits and add unnecessary complexity for both production engineers and operators. This indicates that lean practices should not be applied programmatically but mainly in production processes where standard procedures can be applied most of the time and when the standards can be considered as "robust," i.e., relatively easy to uphold. 
Other common traits are a considerable loss of work richness and of learning possibilities. In all three plants, a loss of craftsmanship and professional pride has thereby come to the fore, resulting in feelings of not caring about work as much as before or of even of resignation. A potential danger in lean practices therefore seems to be the reduction of variation in work content, creating a situation where operators cannot make full use of their competences, in turn leading to a loss of meaningfulness and motivation. In a long-term perspective, operators' alienation is at risk and might lead to a decreased capacity to produce customized goods and/or to develop new production methods (cf. Kamata, 1982). As is evident when implementing lean in the three case study companies, they have not taken this potential danger into full consideration.

Another common trait in all three plants was a withdrawal of tasks having to do with self-management and a feeling of ownership of production, such as having a say as regards daily production, being involved in administrative tasks, personnel issues, tasks involving purchasing and calling off material, working together with other departments, and so forth. All in all, this resulted in a loss of work richness and autonomy and in that same move a loss of engagement, professional pride, and craftsmanship. Besides, work became more stressful.

The danger of losing engagement in relation to a loss of ownership is not only the risk for a decrease of loyalty toward the company or organization but also of the desire to make use of the operators' creative and innovative capacities for the benefit of the company. These dangers were obvious at all three plants, since none of them succeeded in keeping a feeling of operator ownership due to the withdrawal of delegated responsibilities and work assignments.

Coming back to self-management and standardization, we agree with Kamata (1982) and Hackman and Oldham $(1975,1976,1980)$ that taking part in standardization work, so called SOPs (Imai 1986:xxiv), is not enough for claiming that participation or responsible autonomy (important aspects of self-management) has been achieved, fostering engagement, motivation, and increased worker confidence, as suggested by Adler (1993), Edelson and Bennett (1998), and de Treville and Antonovsky (2006). One explanation for this difference in findings might be that our case companies were switching to lean from sociotechnical practices using a much higher degree of participation, delegated responsibilities, and work richness than is the case in companies using traditional mass production line practices. Thus, findings will differ greatly when comparing lean being implemented in sociotechnical practices compared with traditional Tayloristic mass production practices. This is also underlined by the findings of Hasle et al. (2012) in their overview and in accordance with the findings of Landsbergis et al. (1999) and Conti et al. (2006) but also with Börnfelt (2006) and Seppälä and Klemola (2004). Their findings show that the overall negative effects of lean, to be found in industries such as the auto industry and in manual low-complexity jobs, could be counteracted by the use of sociotechnical practices such as employee involvement and participation and with an environment context characterized by a strong sense of trust toward production personnel.

We would also like to point to the fact that on the one hand a sense of self-management is considered important in order to enhance operator engagement and interest in overall production issues and thereby to reach a presumed increase of productivity and profitability (cf. Tengblad, 2003; Thorsrud and Emery, 1969; Oudhuis, 2009). However, on the other hand, as came to the fore in our case companies, the wish for autonomy can 
be perceived as a disadvantage when directives have to be followed as is the case with standards. How to solve this dilemma? One answer we suggest would be to have wider standards along with other work enrichment possibilities.

As regards the different lean models suggested by Hampson (1999), an obvious pattern in all plants has been attempts to implement models that at least partly are in accord with the leanness model, i.e., 1) standardized work sheets, 2) kaizen activities, 3) small buffers, 4) a changeover to line production, and 5) shorter work cycles. However, as explained above, the outcomes of these attempts differ quite radically as regards successful implementations of lean tools such as standardized work sheets and kaizen activities, but also as regards work balance times. However, there has been a clear move in all plants toward a higher degree of pressure on operators, but not comparable to those in Japan, the United States, and the United Kingdom as pointed to by Hampson (1999). It probably has to do with a much more balanced power relationship between the employers and union organizations in Sweden, but also with difficulties to standardize production and/or to use kaizen activities as a speed-up technique.

What about the concept of heijunka mentioned in the introduction part? Attempts have been made to get a more even or balanced flow in production through measures such as letting the 41 and 82 minute vehicles to have different lines at the North plant or by keeping the station assembly as regards the heaviest products in the West plant and so forth. Where kaizen activities have been put forward, they are not leading to excessive overtime. Again, the more equal power relationship between the parties is a likely explanation.

Coming back to our overall research aim asking whether it is possible to combine self-management principles with lean practices and standardization, we argue that when implementing lean, one should begin by negotiating with the operators to enable them to feel ownership of production. We furthermore argue that a significant share of the productivity increases should be handed over to the operators at the group or plant level and thus create incentives to be involved in production changes. The feeling of ownership could be substantiated if operators use self-management techniques in the implementation of more standardized work practices where production engineers can serve as facilitators to the operators. The implementation of lean practices should primarily be aimed to create robust standards for the core of the operations, i.e., even a customized product should be built on a common and standardized frame. The possibility for making customized products can provide variation, enrichment, and a feeling of pride among the operators.

Furthermore, even if production processes become more standardized, we see no need for a change toward a more authoritarian leadership style and a work organization that strongly reduces not only work content but also operators' responsibilities, autonomy, and self-management practices. We argue that production teams can continue to be responsible for calling off goods, for making basic maintenance, and to be in contact with end-users and so forth even if techniques for maintaining and improving work standards are utilized. The often very long production cycles show that operators can succeed even with very complicated work tasks, and the ability and possibility of operators to master the complexity of production when making customized products could be one of the cornerstones for the future competitiveness of Swedish industry. The need for self-management capacities was also strongly underlined in an interview study with a number of CEOs in foreign-owned Swedish companies having implemented lean 
models (Oudhuis, 2008). Abilities to take initiatives of one's own, a willingness to take on delegated responsibilities, and the development of their self-management capacities were considered most essential in keeping the companies competitive on the international market. To keep in mind, however, these companies used lean practices that include strong sociotechnical aspects, in order to ensure these capacities, thus indicating a blend of the two concepts in question.

A final note is that the crucial need of taking the context very seriously, which also could imply factors as to what makes the work meaningful and a source for pride, is in a way to acknowledge that production systems are complex. Successful manufacturing needs to bring together modern technology with human craftsmanship in ways where efficient work processes are combined with flexibility and adaptability. Disturbances cannot completely be avoided and there is a need for learning both on individual and organizational levels. It is unlikely that the use of standardized techniques will be successful if there is little context sensitivity bearing in mind the vast variation in modern industry concerning production volumes, customization, level of automation, the need of work skills, etc. Lean production is by no means the one and only solution for creating efficient workplaces.

\section{Conclusion}

With Hasle et al. (2012), we agree with a concept definition of lean practices that include a strong focus on the human side as an integrated part of a broader sociotechnical system. In doing so, we have in this article argued that it would be possible to combine lean practices and standardization with self-management principles, provided that the above-mentioned prerequisites are met. There is not one way to success in modern production, the key task is to develop practices suited for the product, the competence of the operators, the need of customers, and available technology. In order to achieve this, it is essential with organizational trust, a good flow of information, and a sense of accountability and pride among the production workers. The future of lean production in Sweden and other advanced economies relies on how this challenge can successfully be realized.

\section{References}

Adler, P. S. (1993) The new "learning bureaucracy". New United Motor Manufacturing, Inc. In Staw, B. B. and Cummings, L. L. (Eds). Research in Organizational Behavior, 15. Greenwich, CT: JAI Press, pp. 111-194.

Allvin, M., Aronsson, G., Hagström, T., Johansson, G. and Lundberg, U. (2006) Borderless Work-Perspectives from Social Psychology on the New Working Life. (Gränslöst arbete—socialpsykologiska perspektiv på det nya arbetslivet). Stockholm: Liber.

Björkman, T. (2002) Den långlivade taylorismen. (The long lived Taylorism). In Abrahamsson, K., et al. (Eds). Utbildning, kompetens och arbete (Education, Competence and Work). Lund: Studentlitteratur, pp. 303-334.

Börnfelt, P. O. (2006) Change Competence at the Shop Floor (Förändringskompetens på industrigolvet). Stockholm: Arbetslivsinstitutet: Arbete och Hälsa No 2006:1. 
Conti, R., Angelis, J., Cooper, C., Faragher, B., and Gill, C. (2006) The effects of lean production on worker job stress. International Journal of Operations \& Production Management, 26(9): 1013-1038.

de Treville, S. and Antonakis, J. (2006) Could lean production job design be intrinsically motivating? Contextual, configurational, and levels-of-analysis issues. Journal of Operations Management, 24: 99-123.

de Treville, S., Antonakis, J., and Edelson, N. M. (2005) Disruption, Learning, and System Improvement in Just-in-Time Manufacturing. Dissertation Abstracts International. (University Microfilms No 8717014).

Docherty, P., Forslin, J., (Rami) Shani, A. B., and Kira, M. (2002) Emerging Work Systems. From Intensive to Sustainable. In Docherty, P., Forslin, J., and (Rami) Shani, A. B. (Eds). Creating Sustainable Work Systems. Emerging Perspectives and Practice. London: Routledge, 3-14.

Edelson, N. M. and Bennett, C. L. (1998) Process Discipline: How to Maximize Profitability and Quality Through Manufacturing Consistency. New York: Quality Resources.

European Foundation for the Improvement of Living and Working Conditions (2007). Dublin: Fourth European Working Condition Survey.

Gustavsen, B. (1996) Changes in work organization and public support: The case of the Swedish work life fund. Futures, 28(2): 139-152.

Hackman, J. R. and Oldham, G. R. (1975) Development of the job diagnostic survey. Journal of Applied Psychology, 60(2): 159-170.

Hackman, J. R. and Oldham, G. R. (1976) Motivation through the design of work: test of a theory. Organizational Behavior and Human Performance, 16: 250-279.

Hackman, J. R. and Oldham, G. R. (1980) Work Redesign. Reading. MA: Addison-Wesley.

Hailey, V. H. and Balogun, J. (2002) Devising context sensitive approaches to change: the example of Glaxo Wellcome. Long Range Planning 35, 153-178, www.lrpjournal.com

Hampson, I. (1999) Lean production and the Toyota Production System or, the case of the forgotten productions concepts. Economic and Industrial Democracy, 20(3): 369-391.

Hasle, P., Bojesen, A., Langaa, P., and Bramming, P. (2012) Lean and the working environment: a review of the literature. International Journal of Operations \& Production Management 32(7), 829-849.

Hofstede, G. (1991) Culture and Organizations. Lund: Studentlitteratur.

Imai, M. (1986) Kaizen. New York: Random House.

Jönsson, S. (1995) Good Prospects: Swedish Management in Perspective (Goda utsikter: svenskt management i perspektiv). Stockholm: Nerenius \& Santerus.

Kamata, S. (1982) Japan in the Passing Lane: An Insider's Account of Life in a Japanese Auto Factory. New York: Pantheon Books.

Landsbergis, P. A., Cahill, J., and Schnall, P. (1999) The impact of lean production and related new systems of work organization on worker health. Journal of Occupational Health Psychology, 4(2): 108-130.

Liker, J. K. (2004) The Toyota Way-14 Management Principles from the World's Greatest Manufacturer. New York: McGraw-Hill.

Niepce, W. and Molleman, E. (1998) Work Design Issues in Lean Production from a Sociotechnical Systems Perspective: Neo-Taylorism or the Next Step in Sociotechnical Design? Human Relations, 51(3): 259-285.

Oudhuis, M. (2008) The Local in the Global-The Regional Spirit in Foreign Owned Companies (Det lokala i det globala—om knalleandan i utlandsägda företag). In Brorström, B., Edström, A., and Oudhuis, M. (Eds). Knalleandan-drivkraft och begränsning. Forskningsprogrammet om företagande, traditioner och förnyelse i Sjuhäradsbygden. Högskolan i Borås: Vetenskap för profession, rapport nr 3. 
Oudhuis, M. (2009) Humility Insight or Self-Sufficient Nonchalance, on Governance, Organization and Production Innovation in Large Groups (Ödmjukhetens insikt eller självtillräcklighetens nonchalans, om styrning, organisering och produktionens förnyelse i stora koncerner). In Brorström, B., Edström, A., and Oudhuis, M. (Eds). Framgångsrik förnyelse. Forskningsprogrammet om företagande, traditioner och förnyelse i Sjuhäradsbygden. Högskolan i Borås: Vetenskap för profession, rapport nr 9.

Oudhuis, M. and Olsson, A. (2011) Japanese, Japanese. The importance of culture when switching to Toyota inspired Lean Production in a Japanese owned company in Sweden (Japaner, japaner. kulturens betydelse vid övergången till en toyotainspirerad lean produktion i ett japanskägt företag i Sverige). Arbetsmarknad \& Arbetsliv, (2): 11-17.

Pettigrew, A. M. and Whipp, R. (1991) Managing Change for Competitive Success. Oxford: Blackwell.

Røvik, K. A. (2000) Modern Organizations; Trends in Organizational Thinking at the Millennium (Moderna organisationer: trender inom organisationstänkandet vid millennieskiftet). Malmö: Liber.

Seppälä, P. and Klemola, S. (2004) How do employees perceive their organization and job when companies adopt principles of lean production? Human Factors and Ergonomics in Manufacturing, 14(2): 157-158.

Silverman, D. (2006) Interpreting Qualitative Data: Methods for Analyzing Talk, Text and Interaction. London: Sage.

Susman, G. I. (1976) Autonomy at Work: A Sociotechnical Analysis of Participative Management. New York: Praeger.

Tengblad, S. (2003) The Authoritative Co-worker: Strategies for a Constructive Co-workership. (Den myndige medarbetaren: strategier för konstruktivt medarbetarskap). Malmö: Liber.

Thompson, P. (2003) Disconnected capitalism: or why employers can't keep their side of the bargain. Work Employment and Society, 17(6): 359-378.

Thorsrud, E. and Emery, F. E. (1969) Empowerment and Involvement in the Work: Norwegian Attempts with Selfsteering Teams. (Medinflytande och engagemang $i$ arbetet: Norska försök med självstyrande arbetsgrupper). Stockholm: Utvecklingsrådet för samarbetsfrågor.

Totterdill, P., Dhondt, S., and Milsome, S. (2002) Partners at Work? Brussels: Report from the Hi-Res Project.

Visholm, S. (2005) Undefined roles in postmodern organizations (Uklare roller i postmoderne organisationer). Tidsskrift for Arbejdsliv, 1: 27-42.

Womack, J., Jones, D. T., and Roos, D. (1990) The Machine That Changed the World. New York: Rawson Associates. 